\title{
The first data on the nesting biology of the invasive blue nest-renting wasp, Chalybion turanicum (Gussakovskij, 1935) (Hymenoptera, Sphecidae, Sceliphrinae) in the Crimea
}

\author{
Alexander V. Fateryga', Mykola M. Kovblyuk², Roman S. Kvetkov' \\ I T.I. Vyazemsky Karadag Scientific Station - Nature Reserve of RAS - Branch of A.O. Kovalevsky Insti- \\ tute of Biology of the Southern Seas of RAS, Nauki Str. 24, Kurortnoye, Feodosiya, 298188, Crimea, Russia \\ 2 Taurida Academy, V.I. Vernadsky Crimean Federal University, Yaltinskaya Str. 4, Simferopol, 295007, \\ Crimea, Russia \\ Corresponding author: Alexander V. Fateryga (fater_84@list.ru) \\ Academic editor: R. Yakovlev | Received 23 August 2020 | Accepted 4 October 2020 | Published 26 November 2020 \\ http://zoobank.org/C47B8F6A-B85D-4F1A-9EE9-50C8F3B401A8 \\ Citation: Fateryga AV, Kovblyuk MM, Kvetkov RS (2020) The first data on the nesting biology of the invasive \\ blue nest-renting wasp, Chalybion turanicum (Gussakovskij, 1935) (Hymenoptera, Sphecidae, Sceliphrinae) in the \\ Crimea. Acta Biologica Sibirica 6: 571-582. https://doi.org/10.3897/abs.6.e57911
}

\begin{abstract}
The nesting biology of Chalybion turanicum (Gussakovskij, 1935) has been studied, with a total of 31 nests being examined. All studied nests were located inside the old nest cells of Sceliphron destillatorium (Illiger, 1807). Each nest of Ch. turanicum consisted of a single cell. Females hunted for spiders, with 18 species in five families being identified among their prey. Two most abundant victim groups were Theridiidae (eight species, 54\% of specimens) and Araneidae (seven species, 33\% of specimens) spiders. A spider number stored in a cell varied from five to 31 (mean $=17.6 \pm 5.4$ ). In the Crimea, Ch. turanicum has one generation per year with reproductive success of $67 \%$. Two species of the nest parasites were reared from cells of Ch. turanicum: Chrysis taczanovskii Radoszkowski, 1876 and Acroricnus seductor (Scopoli, 1786). Chalybion turanicum is the seventh invasive species of Sphecidae naturalized in Europe.
\end{abstract}

Copyright Alexander V. Fateryga et al. This is an open access article distributed under the terms of the Creative Commons Attribution License (CC BY 4.0), which permits unrestricted use, distribution, and reproduction in any medium, provided the original author and source are credited. 


\section{Keywords}

Sphecid wasps, invasive species, bionomics, trophic relationships, prey, spiders, reproductive success, Sceliphron destillatorium

\section{Introduction}

The apoid wasp genus Chalybion Dahlbom, 1843 is distributed in all zoogeographical realms and accounts for 49 extant species (Pulawski 2020), most of which are confined to tropical and subtropical regions. A few species of Chalybion have penetrated countries with the temperate climate, such as Russia, where just two native species occur: viz., Chalybion japonicum (Gribodo, 1882) in Primorskiy Territory and Ch. walteri (Kohl, 1889) in the North Caucasus (Danilov 2017). Similarly to other above-ground nesting Sphecidae (i.e., Sceliphron Klug, 1801 and Isodontia Patton, 1880), several species of Chalybion are known to have colonized new territories with the aid of man. For example, two species, i.e., the primarily Oriental Chalybion bengalense (Dahlbom, 1845) and the Nearctic Ch. californicum (de Saussure, 1867), were recently introduced to Europe (Mei et al. 2012, Mei and Bošč́k 2016).

Females of the majority of Chalybion species nest in various preexisting cavities: hollow stems, wood burrows, stone caverns, and abandoned or even operated nests of other hymenopterans, especially closely related genus Sceliphron. The mud is the principal material used for nest partitions and the plug, but instead of collecting already existing mud, the wasps carry water to a source of dry clay soil near their nests and then use it to dampen and plaster the soil (Bohart and Menke 1976, Iwata 1976, Kazenas 2001, Gess and Gess 2014, Pham 2018). In addition to mud, some species use a white material composed of either lime from whitewashed walls or uric acid obtained from bird or reptilian droppings (Jayakar and Spurway 1963, Barthélémy 2011, Pham 2019). Females of at least one species in the subgenus Hemichalybion Kohl, 1918 excavate nests in the non-friable soil of vertical banks with the aid of water (Gess et al. 1982). All species of the genus Chalybion hunt for spiders and store up to several tens of victims in each nest cell. The Chalybion species that are studied bionomically vary in nesting cavity preference, prey composition, number of generations per year, and other bionomical features, which could be important, for instance, the ability to colonize new territories. Thus, Chalybion spinolae (Lepeletier de Saint-Fargeau, 1845) nests in vertical banks and hunts exclusively for Black Widow spiders (the genus Latrodectus Walckenaer, 1805; Theridiidae) and therefore is not synanthropic (Gess et al. 1982, Nel et al. 2014), while some other species are known to nest exclusively in hollow stems of trap-nests and to hunt for Araneidae spiders (Ohl and Höhn 2011, Pham and Dang 2017). Other species hunt for various spiders with the preference to the families Araneidae or Theridiidae. Of them, Chalybion bengalense, Ch. japonicum, Ch. tibiale (Fabricius, 1781), and Ch. zimmermannii (Dahlbom, 1843) are versatile in the nesting substrate selection (Ward 1971, Barthélémy 2011, Gess and Gess 2014, Pham 2018, 2019), whereas Ch. californicum 
nests almost exclusively in the Sceliphron nests (Rau 1928, Horner and Klein 1979, Landes et al. 1987). Chalybion is also one of the sphecid genera that commonly form "sleeping" aggregations, usually consisting of both sexes and sometimes even of two species (Landes and Hunt 1988, Pham 2020).

Chalybion turanicum (Gussakovskij, 1935) is a Palaearctic species native to Iran, Turkmenistan, Uzbekistan, Kyrgyzstan, Tajikistan, and southern and south-eastern Kazakhstan (Kazenas 2001, Danilov 2017). It was accidentally introduced to Russia, where two female individuals were first collected in 2010 from Altai Territory (Baghirov 2011). The next record was made in 2019 from the Crimea, again based on two females (Mokrousov et al. 2019). Little is known about the bionomics of $\mathrm{Ch}$. turanicum. Kazenas (2001) reported that the nest he found in Kazakhstan was made inside $8 \mathrm{~mm}$ wood burrow and females hunted for spiders in tree canopies. On the other hand, Marikovsky (1990) reported on a female of Chalybion sp. (аs "синий сцелифрон" [Blue Sceliphron]) hunting for Latrodectus sp. that occurred on the ground. According to Kazenas (2001), "Blue Sceliphron" was most likely to be Ch. turanicum. No further details were published on the nesting habits of this species. The report on the bionomics of Ch. turanicum by Baghirov (2011), cited also by Pham (2018), can be considered as an extrapolation of the data known for other Chalybion species.

The purpose of our contribution is to provide the first data on the nesting biology of Ch. turanicum in the Crimea, where the species was recently introduced.

\section{Material and methods}

The nests of Chalybion turanicum were initially found in the old nest cells of Sceliphron destillatorium (Illiger, 1807) in Koktebel $\left(44^{\circ} 57.9^{\prime} \mathrm{N}, 35^{\circ} 15.1^{\prime} \mathrm{E}\right)$ in March 2020. The nests of $S$. destillatorium were located under a shed roof and were abandoned by the host species many years ago. Several nests were removed and dissected in the laboratory with a knife, by cutting mud surface layer by layer. A total of 13 nest cells were occupied by Ch. turanicum. Cell contents (cocoons of Ch. turanicum and other insects) from the dissected nests were placed into glass tubes sealed with cotton plugs and kept under outdoor conditions until the emergence of imagoes. Then, the reared wasps were identified. Specimens of Ch. turanicum were deposited in the research collection of M.V. Mokrousov, Nizhny Novgorod.

Nesting females and males of Ch. turanicum were also observed near the dolphinarium of the T.I. Vyazemsky Karadag Scientific Station $\left(44^{\circ} 54.7^{\prime} \mathrm{N}, 35^{\circ} 12.1^{\prime} \mathrm{E}\right)$ in June 2020. The observations were made during one full day and during an hour on two other days within a week. There were several old nests of $S$. destillatorium on the south-facing wall of the dolphinarium, but the wasps did not use them. Instead, they entered a room with freezers through an inoperative exhaust fan (Fig. 1). Five clusters of the old nests of $S$. destillatorium were found on the ceiling of that room, with each cluster consisting of three to five nests made one above another (Figs 3, 
4). Three of these clusters were removed and studied in the laboratory on 29 June (two clusters) and 12 July (the remaining one) that resulted in obtaining additional 18 nest cells of Ch. turanicum, of which 13 were sealed by females in 2020 and the remaining other five represented last-year nests. A total of 12 cells (11 "fresh" and one last-year cell with a dead host's egg) contained the prey items - 211 spider specimens, which were stored in $70 \%$ ethanol and deposited in the arachnological collection of the V.I. Vernadsky Crimean Federal University, Simferopol.

\section{Results}

The studied nests of Chalybion turanicum were found exclusively in the old nest cells of Sceliphron destillatorium. Yet, one nest was found inside an abandoned nest cell of Megachile (Pseudomegachile) ericetorum Lepeletier de Saint-Fargeau, 1841 (Hymenoptera, Megachilidae), which in turn was built up inside a cell of $S$. destillatorium.

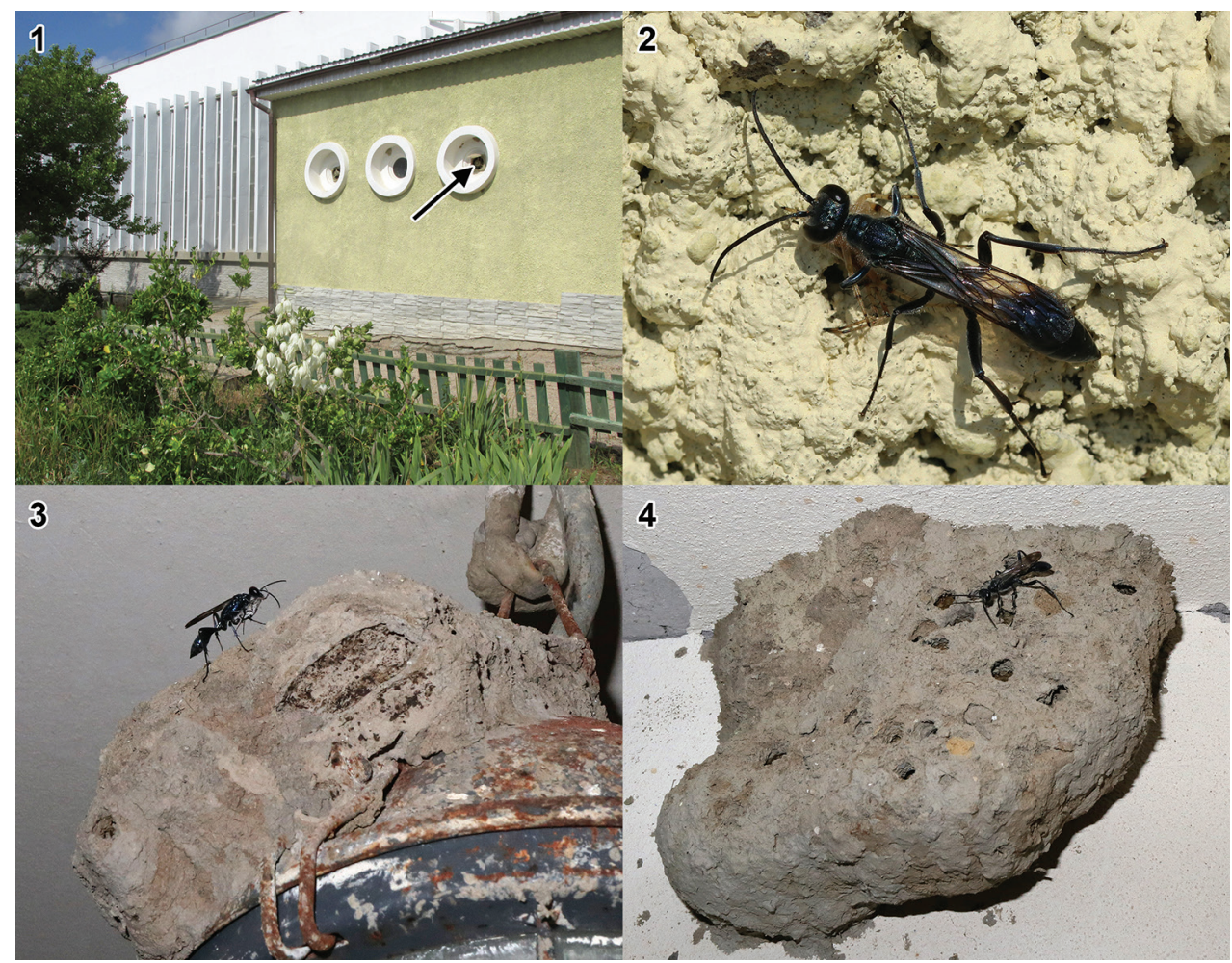

Figures I-4. Nesting of Chalybion turanicum (Gussakovskij, 1935) in the Crimea. I - The nesting site (arrow indicates the entrance to the room with the nests). $\mathbf{2}$ - A female with a victim. 3 - A cluster of nests of Sceliphron destillatorium (Illiger, 1807) with a female of Ch. turanicum arrived with a victim. 4 - Another cluster of nests of $S$. destillatorium with a perching male of Ch. turanicum. 
Thirty other nests of Ch. turanicum were located inside the cells of the latter species itself. Each nest contained a single cell that corresponded to the host species cell. There were no preliminary plugs; only the final plugs of the cells were made by $C h$. turanicum. These plugs were made of grayish mud without any additional white material (Fig. 4). It was impossible to establish whether the wasps used exclusively open cells of $S$. destillatorium (either empty ones or those, from which the host's progeny had emerged), or the cells sealed with mud as well (also either empty or with the dead progeny). Anyway, the females of Ch. turanicum merely filled the cells of $S$. destillatorium with spiders and then sealed them with the plugs (Figs 5, 6). Thus, the wasps either did not clean the cells prior to provisioning, or could clean them insufficiently, so that the provisioned cells contained the remains of old cocoons of the same species (found in two nests; Fig. 7). In addition, the remains of old cocoons of S. destillatorium (Fig. 8) and its nest parasite Chrysis taczanovskii Radoszkowski, 1876 (Hymenoptera, Chrysididae) were also found in the nests of Ch. turanicum at three occasions each (one cocoon of Ch. taczanovskii was found in the same provisioned cell where one old cocoon of Ch. turanicum was present).

The females of Ch. turanicum hunt for spiders (Figs 2, 3). Eighteen species in five families were identified among the studied prey (Table 1). More than a half of the specimens belonged to the family Theridiidae (eight species) and a third to the Araneidae (seven species). Other three families (about 13\% of the caught specimens) were represented by one species each. Among the 211 studied spider specimens, 43 were adults (two males and 41 females) and 168 were juveniles. Most spiders had a total body length of $4-5 \mathrm{~mm}$ and a spherical abdomen. Fourteen specimens, however, were different: these were Argiope spp. (one of them is shown in Fig. 9) and Pholcus phalangioides (seven of them are shown in Fig. 10) with an elongated abdomen and the body length clearly exceeding $5 \mathrm{~mm}$. According to a taxonomic composition of the prey, wasps collected spiders from various habitats, from the ground level up to tree crowns, without any visible preferences. A number of the spiders, stored in a cell (Figs 9, 10), varied from five to 31 ( mean $=17.6 \pm 5.4, \mathrm{n}=12$, $\mathrm{p}=0.05$ ). The spiders, stored in freshly sealed nest cells, often retain some of their life activity, particularly, their legs were trembling. One of the five spiders, found in the last-year cell with a dead egg, even shed its cuticle.

Twelve adult wasps (seven females and five males) emerged from the 18 lastyear cells. Males emerged from 25 May to 13 June, females - from 8 June to 30 June. Two fresh cocoons with diapausing prepupae were found in the nests on 12 July, which is evidence of a single generation per year. A reproductive success amounted to $67 \%$, but the data were not representative. The progeny (an egg and a prepupa) died in two cells for uncertain reason. Other four cells were damaged by two species of nest parasites. One was Acroricnus seductor (Scopoli, 1786) (Hymenoptera, Ichneumonidae, Cryptinae), with its cocoon being found in one of the last-year cells instead of the host cocoon. The larva of A. seductor probably consumed the fifthinstar larva of Ch. turanicum, which had already consumed all the provisioned spiders but had not spun its cocoon yet. An adult male of this parasitoid wasp emerged 
on 7 May. Other three cells contained cocoons of Chrysis taczanovskii among the prey remains. It was impossible to establish whether its larvae fed on the prey or host larvae. Two males of Ch. taczanovskii emerged on 28 and 30 June and a female emerged on 8 July.

The males of Ch. turanicum were observed applying two different mating strategies. Some patrolled several shrubs of Euonymus japonicus Thunb. (Celastraceae) and Juniperus sabina L. (Cupressaceae) which were cultivated at the nesting site (Fig. 1). Others were perching on the clusters of old nests of S. destillatorium inside the room with freezers (Fig. 4). A single male defended each nest cluster. Copulation was not observed.
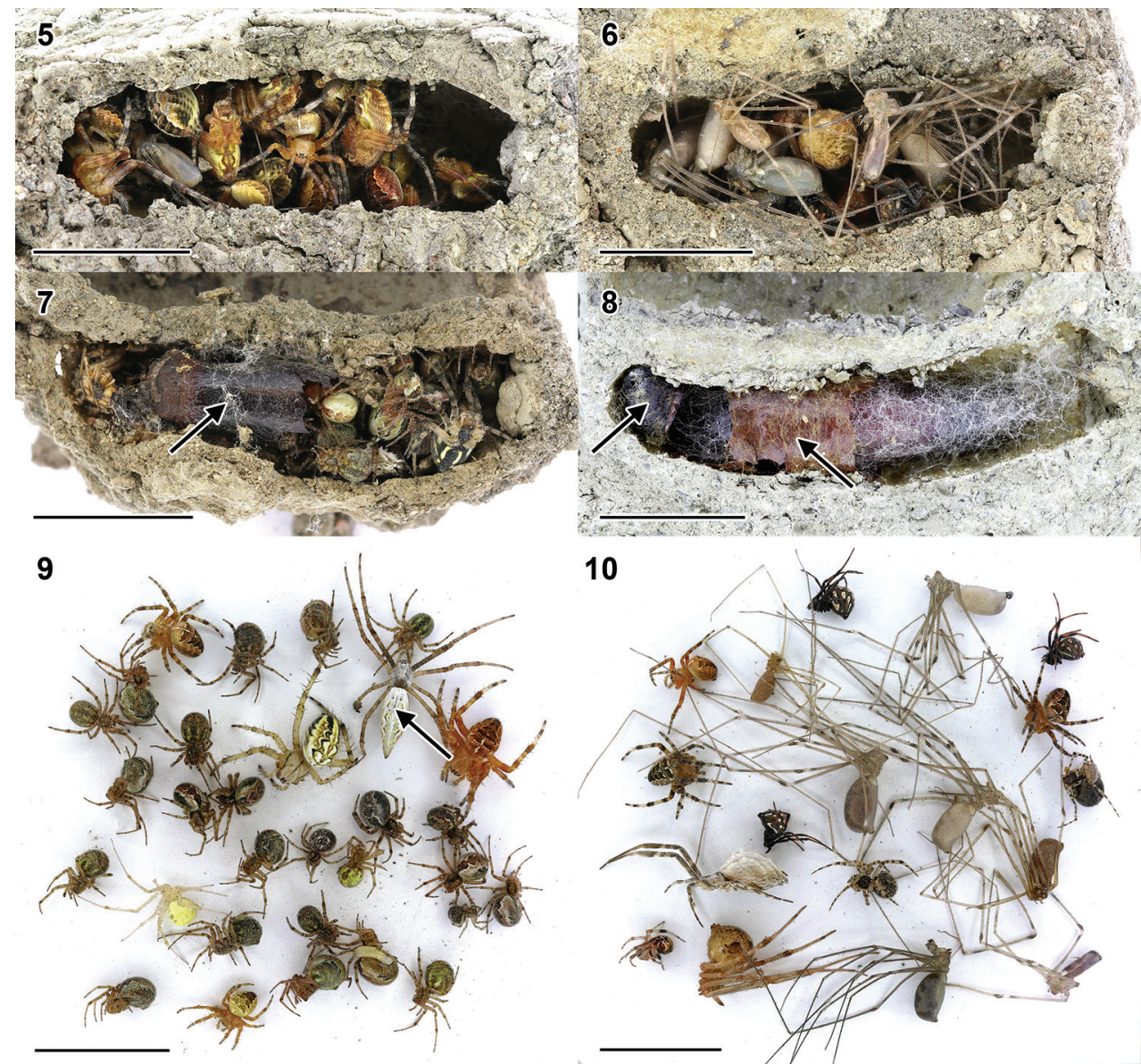

Figures 5-I 0. The nest content of Chalybion turanicum (Gussakovskij, 1935). 5, 6 - Cells with the prey in old nest cells of Sceliphron destillatorium (Illiger, 1807). 7 - A cell with the prey and an old cocoon of Ch. turanicum (arrow). 8 - A cell with a cocoon of Ch. turanicum inside an old cocoon of $S$. destillatorium (arrows). 9, 10 - Spiders from two nest cells, arrow indicates a juvenile specimen of Argiope bruennichi (Scopoli, 1772). Scale bars $1 \mathrm{~cm}$. 
Table 1. Taxonomic composition of the spiders found in 12 nest cells of Chalybion turanicum (Gussakovskij, 1935) in the Crimea.

\begin{tabular}{|c|c|c|}
\hline Family & Species & Number of specimens \\
\hline \multirow{10}{*}{ Araneidae } & Araneus diadematus Clerck, 1757 & 43 juv. 우 \\
\hline & Araneus spp. & 6 juv. \\
\hline & Argiope bruennichi (Scopoli, 1772) & 1 juv. $\hat{\delta}, 1$ juv. 우 \\
\hline & Argiope lobata (Pallas, 1772) & 1 juv. 우 \\
\hline & Cyclosa sierrae Simon, 1870 & 1 우 \\
\hline & Mangora acalypha (Walckenaer, 1802) & 4 우, 1 juv. \\
\hline & Neoscona adianta (Walckenaer, 1802) & 6 ㅇ, 3 juv. \\
\hline & Neoscona subfusca (C.L. Koch, 1837) & 1 우, 1 juv. 우 \\
\hline & Araneidae Gen. sp. & 1 juv. \\
\hline & Subtotal & $70(33.2 \%)$ \\
\hline \multirow{2}{*}{ Mimetidae } & Ero aphana (Walckenaer, 1802) & 1 우 \\
\hline & Subtotal & $1(0.5 \%)$ \\
\hline \multirow{2}{*}{ Pholcidae } & Pholcus phalangioides (Fuesslin, 1775) & $1 \hat{\delta}, 10$ juv. \\
\hline & Subtotal & $11(5.2 \%)$ \\
\hline \multirow{9}{*}{ Theridiidae } & Heterotheridion nigrovariegatum (Simon, 1873) & 1 우 \\
\hline & Kochiura aulica (C.L. Koch, 1838) & $1 \hat{\delta}, 94$ juv. 우 \\
\hline & Latrodectus tredecimguttatus (Rossi, 1790) & 1 juv. $\hat{0}, 4$ juv. 우 \\
\hline & Parasteatoda lunata (Clerck, 1758) & 3 우 \\
\hline & Parasteatoda tepidariorum (C.L. Koch, 1841) & 2 우 \\
\hline & Simitidion simile (C.L. Koch, 1836) & 1 우 \\
\hline & Steatoda triangulosa (Walckenaer, 1802) & 1 우, 1 juv. 우 \\
\hline & Theridion melanurum (Hahn, 1831) & 5 우 \\
\hline & Subtotal & $114(54.0 \%)$ \\
\hline \multirow{2}{*}{ Uloboridae } & Uloborus walckenaerius Latreille, 1806 & 15 우 \\
\hline & Subtotal & $15(7.1 \%)$ \\
\hline Total & & 211 \\
\hline
\end{tabular}

\section{Discussion}

Nesting in abandoned nest cells of various species of the genus Sceliphron was previously known for the majority of the studied Chalybion species: viz., Ch. bengalense, Ch. californicum, and Ch. zimmermannii in S. caementarium (Drury, 1773) (Rau 1928, Ward 1971, Horner and Klein 1979, Landes et al. 1987, Mei et al. 2012), Ch. bengalense and Ch. japonicum in S. madraspatanum (Fabricius, 1781) (Pham 2018, 2019), Ch. japonicum in S. deforme (F. Smith, 1856) (Barthélémy 2011), Ch. tibiale in S. spirifex (Linnaeus, 1758) (Gess and Gess 2014), as well as Ch. femoratum (Fabricius, 1781) in Scelipron sp. (Bitsch 1988). Yet, most of these species can also nest in other cavities. The exception is Ch. californicum, which shows a strong preference to nesting in the Sceliphron nests, even in operated ones (Rau 1928). We revealed that Ch. turanicum seems to also prefer the Sceliphron nest cells, since none of its nests 
was found in other types of preexisting cavities (e.g., in trap nests installed every year at the T.I. Vyazemsky Karadag Scientific Station); yet, a nest of this species was earlier found in a wood burrow (Kazenas 2001).

Chalybion turanicum belongs to the Ch. bengalense species group sensu Hensen (1988). Species of this and Ch. tibiale group are renowned for sealing their nests with an additional layer of white material, composed of either lime from whitewashed walls, or uric acid, obtained from bird or reptilian droppings (Jayakar and Spurway 1963, Ward 1971, Barthélémy 2011, Gess and Gess 2014, Pham 2018, 2019). According to Bohart and Menke (1976), such behavior correlates to the structure of the female mandible having an inner subapical tooth in Ch. tibiale and Ch. bengalense groups (Hensen 1988). This subapical tooth is absent from $C h$. californicum, which does not apply an additional white covering in its nests. In Ch. turanicum the tooth is present, but the white nest covering was not observed. Thus, the nesting habits of Ch. turanicum are more similar to those of Ch. californicum than other species of the genus, in particular to Ch. bengalense group. It is noteworthy that Ch. californicum is able to open the freshly sealed nest cells of $S$. caementarium, remove their contents, and then use them for their own nesting (Rau 1928). The same behavior is also described for Ch. japonicum using the S. deforme nests (Barthélémy 2011). It was impossible to establish whether such peculiar habits exist in Ch. turanicum, because all the nests of S. destillatorium, analysed in our study, were abandoned many years ago, apparently due to the decrease of the population of $S$. destillatorium in the Crimea, caused by the invasion of such congeners as S. curvatum (F. Smith, 1870) (Fateryga and Kovblyuk 2013, 2014) and S. caementarium.

The use of old cells without properly cleaning them from old cocoons seems not to be typical in other studied Chalybion species. A similar habit was reported for Ch. femoratum, which nests in old nest cells of Sceliphron sp. (Bitsch 1988).

The diet of Ch. turanicum is typical of the genus Chalybion, consisting of various spiders, with the preference to Theridiidae and Araneidae. Such a composition of prey is most similar to that of Ch. californicum (Rau 1935, Horner and Klein 1979, Landes et al. 1987). Other species are known to hunt for various spiders with the preference to Araneidae: e.g., Ch. bengalense (Chakrabarti 1986, Pham 2019), Ch. japonicum (Barthélémy 2011), and Ch. tibiale (Gess and Gess 2014), or exclusively for Araneidae: Ch. sulawesii Ohl, 2011 (Ohl and Höhn 2011) and Ch. malignum (Kohl, 1906) (Pham and Dang 2017). Only species from the subgenus Hemichalybion hunt exclusively for Theridiidae: e.g., Ch. femoratum (Bitsch 1988) and Ch. spinolae (Gess et al. 1982, Nel et al. 2014); the latter species even specializes in a prey on the single genus Latrodectus, commonly known as Black Widow spiders. Chalybion turanicum was also known as a hunter for Latrodectus (Marikovsky 1990, Kazenas 2001), and our study confirms those observations. Although only five specimens of Latrodectus tredecimguttatus were found in the nest cells of Ch. turanicum, it is worth mentioning that this spider species was indeed rare in the Karadag State Nature Reserve with just five other specimens being earlier known from 14,419 specimens of adult spiders, collected from that site during 12 years (Kovblyuk et 
al. 2015). Such a preference to the genus Latrodectus is also similar to that of Ch. californicum having similar nesting habits, as was stated above.

One can assume that the females of Ch. turanicum collected specimens of Pholcus phalangioides because they occurred near their nests. Nevertheless, it was hardly possible because spider-hunting wasps usually do not attack their victims at their nesting sites (Obin 1982).

Both Ch. turanicum and Ch. californicum differ in their prey preferences from co-occurring Sceliphron species. For example, S. destillatorium prefers Araneidae and Oxyopidae (Fateryga and Kovblyuk 2014), S. caementarium prefers Araneidae and Thomisidae (Horner and Klein 1979), and S. curvatum prefers Araneidae, Salticidae, and Philodromidae (Fateryga and Kovblyuk 2013). At the same time, most of these spider families except Araneidae are absent or only occasionally found in the nests of Ch. californicum (Horner and Klein 1979, Landes et al. 1987) and Ch. turanicum, although they are sometimes present in the prey of Ch. bengalense (Chakrabarti 1986). In its turn, some Sceliphron wasps only occasionally collect Theridiidae spiders, e.g., S. curvatum (Fateryga and Kovblyuk 2013).

Acroricnus seductor and Chrysis taczanovskii reared from the nests of Ch. turanicum are the typical nest parasites of Sceliphron spp. The former species was already reported as a parasitoid of the invasive Ch. bengalense (inside a nest of S. caementarium) in Europe (Mei et al. 2012). Actually, there are no substantial differences between a Sceliphron cell and that of Chalybion occupying it. Both look the same and contain similar sphecid larvae and spiders as the provision. Thus, it is hardly surprising that Ch. taczanovskii, which was previously known as a nest parasite of $S$. destillatorium (Fateryga and Kovblyuk 2014), was reared from the studied nests of Ch. turanicum. This species of cuckoo wasps is highly specialized on the Sceliphron nests. Despite it being found in a nest of the eumenine wasp Euodynerus disconotatus (Lichtenstein, 1884) (Hymenoptera, Vespidae, Eumeninae), that nest was also located inside an old S. destillatorium cell (Martynova and Fateryga 2015). Further studies are needed to determine whether the larva of Ch. taczanovskii feeds on different preys (spiders and caterpillars) or on the host larva.

Chalybion turanicum is the seventh invasive species of Sphecidae naturalized in Europe after the Nearctic Isodontia mexicana (de Saussure, 1867) and S. caementarium, the primarily Oriental S. curvatum, S. deforme, and Ch. bengalense, and the Nearctic Ch. californicum (Schmid-Egger and Herb 2018). Further observations will certainly reveal its expansion to other territories, influenced by climate change, although such an expansion could be not as rapid as in the case of S. curvatum, which has two generation per year (Fateryga and Kovblyuk 2013) and therefore spreads very rapidly.

\section{Acknowledgements}

Mikhail M. Mokrousov (Nizhny Novgorod, Russia) kindly confirmed the identification of the studied material as Chalybion turanicum. Kateryna V. Martynova (Kyiv, 
Ukraine) kindly confirmed the identification of the cuckoo wasp. Dmitri V. Logunov (Manchester, UK) was kind enough to improve our English. An anonymous reviewer provided several helpful suggestions improved the text as well.

The work of A.V. Fateryga and R.S. Kvetkov was a part of the State research project No. AAAA-A19-119012490044-3.

\section{References}

Baghirov RT (2011) First record of the digger wasp Chalybion turanicum (Gussakovskij, 1935) (Hymenoptera: Sphecidae) from Russia. Far Eastern Entomologist 222: 24.

Barthélémy C (2011) Notes on the biology of the conspicuous mud dauber wasp, Chalybion japonicum (Gribodo, 1883) (Sphecidae) a major predator of spiders in Hong Kong. Hong Kong Entomological Bulletin 3(1): 7-14.

Bitsch J (1988) Captures de Chalybion femoratum dans le Midi de la France et observation d'un nid [Hym. Sphecidae]. Bulletin de la Société Entomologique de France 93(1-2): 43-52.

Bohart RM, Menke AS (1976) Sphecid wasps of the world. A generic revision. University of California Press (Berkeley, Los Angeles, and London), ix + 695 pp.

Chakrabarti S (1986) Prey species of the renting wasp, Chalybion bengalense (Dahlbom) (Sphecidae). Sphecos 13: 50.

Danilov YuN (2017) Family Sphecidae - sphecid digger wasps. In: Lelej AS, Proshchalykin MYu, Loktionov VM (Eds) Annotated Catalogue of the Hymenoptera of Russia. Volume I. Symphyta and Apocrita: Aculeata. Proceedings of the Zoological Institute RAS, Supplement 6: 212-216. https://doi.org/10.31610/trudyzin/2017.supl.6.5

Fateryga AV, Kovblyuk MM (2013) Nesting ecology of the digger wasp Sceliphron curvatum (F. Smith, 1870) (Hymenoptera, Sphecidae) in Ukraine. Euroasian Entomological Journal 12(3): 309-314. [in Russian]

Fateryga AV, Kovblyuk MM (2014) Nesting ecology of the wasp Sceliphron destillatorium (Illiger, 1807) (Hymenoptera, Sphecidae) in the Crimea. Entomological Review 94(3): 330-336. https://doi.org/10.1134/S001387381403004X

Gess FW, Gess SK, Weaving AJS (1982) Some aspects of the ethology of Chalybion (Hemichalybion) spinolae (Lepeletier) (Hymenoptera: Sphecidae: Sphecinae) in the Eastern Cape Province of South Africa. Annals of the Cape Provincial Museums. Natural History 14(5): 139-149.

Gess SK, Gess FW (2014) Wasps and bees in Southern Africa. South African National Biodiversity Institute (Pretoria), iv + 320 pp. (SANBI Biodiversity Series 24).

Hensen RV (1988) Revision of the nominate subgenus Chalybion Dahlbom (Hymenoptera, Sphecidae). Tijdschrift voor Entomologie 131: 13-63.

Horner NV, Klein JH (1979) Spider prey of two mud dauber wasp species in Comanche County, Oklahoma (Hymenoptera: Sphecidae). Environmental Entomology 8(1): 3031. https://doi.org/10.1093/ee/8.1.30

Iwata K (1976) Evolution of instinct. Comparative ethology of Hymenoptera. Amerind Publishing Company (New Delhy), xii + 536 pp. 
Jayakar SD, Spurway H (1963) Use of vertebrate faeces by the sphecoid wasp Chalybion bengalense Dahlb. Journal of the Bombay Natural History Society 60(3): 748-749.

Kazenas VL (2001) Fauna i biologiya royushchikh os (Hymenoptera, Sphecidae) Kazakhstana i Sredney Azii [Fauna and biology of sphecid wasps (Hymenoptera, Sphecidae) of Kazakhstan and Central Asia]. KazgosINTI (Almaty), 334 pp. [in Russian]

Kovblyuk MM, Gnelitsa VA, Nadolny AA, Kastrygina ZA, Kukushkin OV (2015) Spiders (Arachnida: Aranei) of the Karadag Nature Reserve (Crimea). Ekosistemy 3: 3-288. [in Russian]

Landes DA, Hunt JH (1988) Occurrence of Chalybion zimmermanni zimmermanni Dahlbom in a mixed sleeping aggregation with Chalybion californicum (Saussure) in Missouri (Hymenoptera: Sphecidae). Journal of the Kansas Entomological Society 61(2): $230-231$.

Landes DA, Obin MS, Cady AB, Hunt JH (1987) Seasonal and latitudinal variation in spider prey of the mud dauber Chalybion californicum (Hymenoptera, Sphecidae). Journal of Arachnology 15(2): 249-256.

Marikovsky PI (1990) Chernaya vdova (Povest' o yadovitom pauke kararurte i drugikh paukoobraznykh) [Black Widow (A tale on the poisonous spider Karakurt and other arachnids)]. Kazakhstan (Alma-Ata), 192 pp. [in Russian]

Martynova KV, Fateryga AV (2015) Chrysidid wasps (Hymenoptera, Chrysididae) - parasites of eumenine wasps (Hymenoptera, Vespidae: Eumeninae) in Crimea. Entomological Review 95(4): 472-485. https://doi.org/10.1134/S0013873815040090

Mei M, Boščík I (2016) Evidence of the introduction into Europe of the Nearctic muddauber wasp Chalybion californicum (de Saussure) (Hymenoptera, Sphecidae). Boletín de la Sociedad Entomológica Aragonesa 58: 239-240.

Mei M, Pezzi G, de Togni R, Devincenzo U (2012) The oriental mud-dauber wasp Chalybion bengalense (Dahlbom) introduced in Italy (Hymenoptera, Sphecidae). Ampulex 5: 37-41.

Mokrousov MV, Shorenko KI, Shlyakhtenok AS (2019) New data on the Palaearctic digger wasps (Hymenoptera: Sphecidae, Crabronidae). Far Eastern Entomologist 396: 10-16. https://doi.org/10.25221/fee.396.2

Nel E, Kelly J, Dippenaar-Schoeman A (2014) Notes on the biology of the wasp, Chalybion spinolae (Hymenoptera: Sphecidae), an obligatory predator of Latrodectus (Araneae: Theridiidae) spiders in South Africa. Journal of Natural History 48(25-26): 1585-1593. https://doi.org/10.1080/00222933.2013.877993

Obin MS (1982) Spiders living at wasp nesting sites: what constrains predation by muddaubers? Psyche 89(3-4): 321-335. https://doi.org/10.1155/1982/76031

Ohl M, Höhn P (2011) Taxonomy, bionomics, and ecology of a new species of the blue muddauber wasp genus Chalybion from Sulawesi (Hymenoptera, Apoidea). Zoosystematics and Evolution 87(2): 335-348. https://doi.org/10.1002/zoos.201100011

Pham PH (2018) Notes on nesting and gregarious behavior of a blue nest-renting wasp, Chalybion japonicum (Gribodo) with comments on commonly used name for Chalybion species (Hymenoptera: Sphecidae). Entomologica Americana 124(1-4): 35-38. https://doi.org/10.1664/1947-5136-124.1.35 
Pham PH (2019) The nesting habits of Chalybion bengalense (Dahlbom) (Hymenoptera: Sphecidae). Oriental Insects 54(3): 308-318. https://doi.org/10.1080/00305316.2019.1 624220

Pham PH (2020) The sleeping aggregative habits of two blue nest renting wasps of the genus Chalybion (Hymenoptera: Sphecidae). Oriental Insects. https://doi.org/10.1080/003053 16.2020.1794995

Pham PH, Dang HT (2017) New record of the mud dauber wasp Chalybion malignum (Kohl, 1906) (Hymenoptera: Sphecidae) from Vietnam with the first information on its nesting biology. Punjab University Journal of Zoology 32(1): 155-158.

Pulawski WJ (2020) Catalog of Sphecidae sensu lato. https://www.calacademy.org/scientists/projects/catalog-of-sphecidae (accessed 15 August 2020).

Rau P (1928) The nesting habits of the wasp, Chalybion caeruleum. Annals of the Entomological Society of America 21(1): 25-35. https://doi.org/10.1093/aesa/21.1.25

Rau P (1935) The wasp, Chalybion cyaneum Fab., preys upon the Black Widow spider, Latrodectus mactans Fav. (Hymen., Araneae). Entomological News 46(10): 259-260.

Schmid-Egger C, Herb G (2018) Ein weiterer Nachweis von Chalybion californicum (de Saussure, 1867) in Europa (Hymenoptera, Sphecidae). Ampulex 10: 35-37.

Ward GL (1971 [“1970”]) Nest site preference of Chalybion zimmermanni Dahlbom (Hymenoptera, Sphecidae). Proceedings of the Indiana Academy of Science 80: 264-266. 